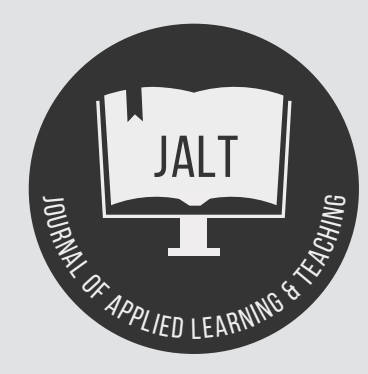

Vol.1 No.1 (2018)

Journal of Applied Learning \& Teaching

Content Available at : http://journals.sfu.ca/jalt/index.php/jalt/index

\title{
Hall, R. \& Winn, J. (Eds.). (2017). Mass intellectuality and democratic leadership in higher education. London: Bloomsbury.
}

Jürgen Rudolph

Senior Lecturer and Academic Partner Liaison, Academic Faculty, Kaplan Higher Education Singapore

DOI: https://doi.org/10.37074/jalt.2018.1.1.8

Mass Intellectuality and Democratic Leadership in Higher Education is a volume that under normal circumstances, I would have been unlikely to read. To mention but a few reasons, the book has a relatively high price tag (it costs $£ 89.99$, and is also available as an e-book at £80.99); and in at least some of the articles, radical leftist positions are taken. However, thanks are due to a charismatic friend who recommended it for review and facilitated contact with one of the editors and the publisher, and I am glad that I read the book.

Not only is the publication - edited by Richard Hall, a Professor of Education and Technology at De Montford University, and Joss Winn, a Senior Lecturer and Programme Leader in Education at the University of Lincoln - intellectually stimulating, there are also persuasive arguments and indubitable academic excellence to be discovered. While my own political and philosophical positions are quite different from (and on occasion, diametrically opposed to) the views of the books that are frequently 'Marxist' from a wide variety of such positions, I was surprised by a great number of points that I would also regard as valid. To me, a considerable value of the book lies in the different perspectives, often from the fringes, that I rarely encounter in my present work and life context - ranging from the more mainstream environmentalism and feminism to radical pedagogy, critical theory, Marxism and even anarchism (p. 2).

The book's opening premise is that higher education $(\mathrm{HE})$ in the UK and beyond is in crisis and the idea of the public university is under assault (p. 2). HE has become increasingly "financialised and marketized" (p. 1). Financialization refers to "deregulation to attract forprofit providers, the commodification of knowledge, curtailment of collegiality, academics as entrepreneurs and the repurposing of students as consumers and protoemployees" (Neary, p. 41). Marketization connotes "the imposition of market principles through the (re)emphasizing of the rhetoric of 'student as customer"' (Saunders, p. 157). $\mathrm{HE}$ has also become increasingly unaffordable not only in
Britain, but worldwide. In the words of student protesters in California in 2009 (during the tail end of the Great Financial Catastrophe):

"We work and we borrow in order to work and to borrow. And the jobs we work toward are the jobs we already have. Close to three quarters of students work while in school, many full-time; for most, the level of employment we obtain while students is the same that awaits after graduation" (quoted in Shukaitis, p. 23).

Increased student fees have led to "rising levels of student and institutional debt", and there is "increased performance management within and across institutions, through the imposition of teaching and research metrics; a lack of transparency and accountability from managers to the students and academics who labour inside the universities"; "and the diminution of its potential social agenda beyond the market" (p. 2). Consequently, the following questions are worth asking: What has led to the crisis and are there any alternatives? Is it possible to reimagine the university democratically and cooperatively?

Many potential readers may be mystified by the term 'mass intellectuality' in the book's title. Thankfully, this central and scintillating concept is discussed in various parts of the volume. It builds on Marx's notion of the 'general intellect' of society which refers to "its general capacity for science in the broadest sense" (p. 3), or the faculty and power to think. In a capitalist system, the 'general intellect' is absorbed into technology that reduces costs and increases productivity, but it is also "a way of capturing the possibility for human emancipation through the social power of the knowledge of humanity" (Neary, p. 50). 'Mass intellectuality' encompasses "the faculty of language, the disposition to learn, memory, the power of abstraction and relation and the tendency towards self-reflexivity" (Virno, quoted in p. 3). While mass intellectuality, just like Marx's general intellect, is being "valorized" (referring to the not very intuitive English translation of Marx's Verwertung - i.e. the productive use 
of a resource so that it makes money) and exploited by capital, it also has a "critical and reconstructive potential for new forms of sociality" (p. 3). In the context of $\mathrm{HE}$, mass intellectuality may play a critical part in liberating knowledge, skills, practices and techniques in order to create democratic, co-operative alternatives to the status quo.

The editors exemplify their answer to 'what is to be done?' by referring to social, multi-stakeholder cooperatives such as Mondragón University in Spain's Basque region. Stakeholders of Mondragón University (MU) include academics and non-academic employeeowners, students and members of the local community, with each of the University's four faculties autonomous and with democratically-elected leaders (p. 14). It may have been worthwhile considering to elaborate in a more detailed way on this example. On the surface, it seems to be a relatively small university with only approximately 4,000 students (www.mondragon.edu), and the faculties appear to be largely geared to feed into local business needs - Engineering, Business Studies, Humanities and Education, and Gastronomic Sciences - plus an innovation and entrepreneurial centre. Also, a headline of an article in popular Spanish newspaper El País in 1997 appeared to support this business-friendly interpretation of a private university: "The cooperatives of Mondragón create a private university oriented to companies" (Las cooperativas de Mondragón crean una universidad privada orientada a las empresas).

One wonders whether this buisness-friendly, private university is really the "best example" (p. 14) of the editors' vision of a new university. To me, MU certainly immediately aroused my interest, as I also think that there is room for improvement for universities becoming learning organisations / knowledge-creating organisations - and I also believe that having flatter organisational structures where multiple stakeholders sit at a (virtual) roundtable as equals would benefit the creation of new knowledge. The editors also refer to 850 schools in the UK that have become multi-stakeholder co-operatives and see that as a possible reference point for new models of $\mathrm{HE}$.

The book is divided into three parts: (1) Power, History and Authority, (2) Potentialities, and (3) Praxis. In addition to the editors' introductory article and a concluding contribution, there are 13 pieces by approximately 20 co-authors (including the anonymous, multi-author "Birmingham Autonomous University") that are more or less equally distributed over these three sections. The book is published by Bloomsbury Publishing (a British independent, worldwide publishing house of fiction and non-fiction that is famous for J.K. Rowling's Harry Potter series) and is part of an exciting series on Perspectives on Leadership in Higher Education. It includes detailed notes on the contributors, exhaustive references and a voluminous index. Nonetheless, the volume is refreshingly concise, totalling only around 260 pages.

The book's first section focuses on Power, History and Authority. Stevphen Shukaitis' (University of Essex) entertaining contribution discusses academic labour as a form of self-exploiting entrepreneurship. I could certainly sympathise with this view when I was writing this book review over the Chinese New Year holidays in Singapore. Related to this observation is the self-description of some of the authors as belonging to the 'precariat', a brilliant neologism that refers to academics and other people who suffer from precarity, a condition of existence without predictability or security, thus affecting their financial and psychological welfare.

Tom Woodin (UCL Institute of Education) critically discusses the historical development of co-operative $\mathrm{HE}$ in Britain by focusing on a case study, Manchester's Co-operative College. Woodin highlights the small enrolment numbers at the College (with only about thirty students as opposed to hundreds of thousands that pass through British universities in 1939 - p. 36) as well as the "continuing marginalization of women in the movement" (p. 37). Mike Neary conducted a series of interviews with 16 academics who have raised their voices against the perceived assault on universities and also reflects on his own experience as the Dean of Teaching and Learning at the University of Lincoln. Professor Neary's incisive qualitative research unearthed some scathing criticism of university leaders and found general agreement on a "culture of conformity among academics" (p. 48) and a fractured student movement.

Martin Paul Eve's (Birkbeck, University of London) contribution is certainly amongst my favourites in the book. Professor Eve is a renowned expert on open access publications that he defines as follows:

\begin{abstract}
"Open access means reconfiguring how we publish academic work so that peer-reviewed scholarly research is available freely to the reader on the world wide web (relying on digital technology to allow instant, near-free copying)" (Eve, p. 56).
\end{abstract}

It is hoped that open access (OA) "will broaden access to education and knowledge, reduce costs, enhance the impact and reach of scholarship and education, and foster the development of more equitable, effective, efficient, and transparent scholarly and educational processes (Velatsianos \& Kimmons, quoted in Eve, p. 57). This is a project that is also very dear to me and JALT aims to be a humble contribution to that purpose.

Eve's excellent contribution guides us through the jargon of gold, green, gratis and libre $\mathrm{OA}$ and has strong data on the impressive profit margins of academic publishers such as, for instance, Elsevier and Taylor \& Francis / Routledge that unsurprisingly, may be wary of OA journals. Professor Eve is the founder of the Open Library of Humanities and has generously published much of his work as OA - this would have also been a consideration for this book on Mass Intellectuality which would have certainly increased its mass appeal.

The book's second section examines Potentialities for change in HE. Joyce Canaan (Birmingham City University) explores how 'neoliberal managerialism' produces 
experiences of "exhaustion, stress, overload, insomnia, anxiety, shame, aggression, hurt, guilt... fraudulence and fear of exposure" (Gill, quoted in Canaan, p. 70) as well as 'hegemonic' competition between students, academic, departments and universities. Her article contains a captivating case study of the Brazilian Landless Movement.

Eurig Scandrett (Queen Margaret University) perceives the current crises in $\mathrm{HE}$ as opportunities and explores several compelling case studies (including the Bhopal survivors' movement study). His discussion of the "growth in problems of managerialism" mirrors the discussion in other parts of the books and is particularly eloquent: it includes "bureaucratization of normal academic work, micromanagement, surveillance, productivity requirements, performance management, deprofessionalization, intimidation, creeping managerial powers in unaccountable non-management positions, divisiveness and outright bullying" (pp. 92-93).

Jenny Pearce (London School of Economics) reflects on Bradford's 'Community University' (a.k.a. 'CommUNity') experiment that opened up new ways of articulating the rich knowledge of its participants. CommUNity was launched by a fascinating variety of people: community workers, a professor, "an Imam, an asylum seeker, a theatre director, an ex-prisoner, a diversity Officer, lecturers, paid and unpaid activists" (Midgely, quoted in Pearce, p. 102).

Jonathan Owen Clark and Louise H. Jackson (both from Trinity Laban Conservatoire of Music and Dance) explore aesthetic education and critical pedagogy in specialist institutions (music, dance, drama, and the fine arts). They provide an alternative vision of HE in such 'art schools' that "reconstructs their position as museums and gatekeepers of a cultural heritage that demarcates an elitist capital, but rather sees them both as guardians of the perpetual and the imaginative, and also as providers of something additional: a thorough education that situates the arts in a globalized context, which is able to not just assimilate, but critique that context" (Clark \& Jackson, p. 125).

The book's final section is rooted in Praxis and explores alternative initiatives that transcend the traditional space of the university. Birmingham Autonomous University - a group of ten university students, graduates and workers who are describing themselves as "communists" (p. 137) offer some theses on the collective failings of the hegemonic university, and this is easily the most radical contribution to the collection. There are eye-catching headers in the article such as "The university is a factory, burn it down" (p. 130). Students are regarded as "workers" that need to learn how to "fight" "against their masters" (p. 131). The shocking belief is expressed "that under capitalism, HE is more socially damaging than it is useful, and that the world as we know it would be a slightly better place without it" (p. 134). The "destruction of the methodological university" or the "abolition of the university as we know it" (p. 140) is proposed, and perhaps surprisingly, MOOCs are viewed as having some potential in that endeavour. In my view, the contribution by Birmingham Autonomous University is certainly extremely troubling, as I personally cherish universities and hold them in high esteem. I have seen their positively life-changing effects in many of my former students (with whom I have kept in touch over the years) and also in my own biography as a lifelong learner.

Joel Lazarus (a self-described member of the 'precariat') attempts to reconcile the apparent contradiction of mass intellectuality with higher education with reference to an intriguing alternative education project in Oxford called People's Political Economy (PPE) that applied some of Paolo Freire's principles of revolutionary pedagogy. Freire's famous revolutionary pedagogy certainly has its compelling aspects, such as its foundations in people's own lived experiences, it being 'dialogical from the outset', nonhierarchical, and having faith in people's capacity for critical discovery and transformation (Lazarus, p. 149) - much of this may sound like a student-centric approach that is quite mainstream in contemporary $\mathrm{HE}$, but of course sans the revolutionary zeal.

Gary Saunders (University of Lincoln) provides an excellent overview of the $2010 \mathrm{HE}$ reforms in the UK. He also offers very useful summaries of philosophical models of democratic pedagogy, summarises noteworthy case studies such as the Social Science Centre (Lincoln) and proposes co-operative education as a new model of $\mathrm{HE}$.

Thomas Henfrey's (Schumacher Institute, Bristol) contribution is rooted in the ethics of environmentalism and has an intriguing title that includes "permaculture education". While permaculture usually refers to the development of agricultural ecosystems intended to be sustainable and self-sufficient, social permaculture "creates a context where each individual can flourish and grow on their own terms while at the same time maximizing their contributions to needs emergent at the level of the group" (p. 172).

Sara C. Motta (University of Newcastle, Australia) discusses various indigenous communities in Colombia and Australia from a feminist and critical, anti-(neo)colonial perspective. Dr Motta sees the need for an "epistomelogical decolonization" that leads to a shift in the geography of knowledge away from universities in the so-called North. She ends "with an invitation to unlearn dominant knowledge practices and subjectivities, and enact epistemological decolonization through entering the epistemological margins and borderlands" in which creativity and power can be found (p. 194).

Gordon Asher's (another self-described member of the 'precariat') concluding chapter emphasises the heterogeneous composition of the contributors and provides an intriguing insight in the collaborative processes that culminated in the book. The extensive co-production, the process of dialogical open peer review (p. 203), deliberations and negotiations could serve indeed as a model of mass intellectuality and democratic review and publication processes.

The book's editors, Professor Hall and Dr Winn, work at UK universities, and the overwhelming majority of the contributors to Mass Intellectuality are also British residents. This leads to a focus on, and, to some extent perhaps even, 
bias toward, UK developments in HE (which, to me, as I work with a few UK universities, certainly made for rather interesting reading). Although there are many examples from outside the UK in the book, it could be argued that a more global perspective - with a greater geographical diversity - would have been more appropriate to the spirit of the tome.

Much could be said about the leftist bias of the volume, but to me, it was certainly a positive that there is no uniform doctrine and various articles critiqued orthodox Marxist views. As mentioned at the beginning of the review, I found it refreshing to reflect on a varied collection of very different views than the mainstream. While many of the observations in the book ring true - for instance, those about academic self-exploitation and the stressfulness and long hours of an academic's - and a working student's - existence; the 'student-as-customer' fallacy; the apparently everincreasing tuition fees and the related indebtedness of graduates in the UK and other countries - to me, the general tone of the book is too negative.

Personally, I have extremely fond memories of my undergraduate studies in Germany, which were of a high quality and provided me with a huge degree of freedom and potentialities during and after my studies. The German example of heavily-subsidised, high-quality tertiary education runs counter to British HE (where students leave university with some of highest debt levels in the world) and perhaps does not conveniently fit into the themes of this remarkable book. The German model of as-good-asfree $\mathrm{HE}$ is far from unique and can also be found in other countries: Norway, Denmark, Finland, Sweden etc; not to mention very affordable university education in numerous other countries like France, Italy, Greece, Argentina, Taiwan etc.

Doubt can also be cast at the occasional assertions in the volume that students are not substantially better off financially and otherwise - due to their university studies over the long run. There are numerous studies which support that there is indeed a good Return on Investment to be had for many graduates. While there may be no simple answer as to whether college is worth it (from a purely monetary perspective), and hard subjects like engineering and finance tend to fare better than arts and humanities, there are also innumerable intangible benefits that a university education gives: to mention but a few, it exposes us to new research and technology as well as to other cultures and backgrounds, fosters creative and independent thinking, and builds initiative and leadership skills. A look at any university's graduate outcomes may serve as a useful reminder of the value of $\mathrm{HE}$.

Mass Intellectuality certainly more than delivers the Bloomsbury Series Editors' request for an alternative perspective on intellectual leadership in HE (Asher, p. 200). For some pieces, the quote misattributed to Voltaire may apply: "I disapprove of what you say, but I will defend to the death your right to say it". On the whole, despite some bias and some perceived shortcomings, this is a remarkable book that is certainly worthwhile reflecting upon for all who care about the future of $\mathrm{HE}$ and how to make it better.

Copyright: @ 2020 Jürgen Rudolph. This is an open-access article distributed under the terms of the Creative Commons Attribution License (CC BY). The use, distribution or reproduction in other forums is permitted, provided the original author(s) and the copyright owner(s) are credited and that the original publication in this journal is cited, in accordance with accepted academic practice. No use, distribution or reproduction is permitted which does not comply with these terms. 